\title{
How good is a living donor? Systematic review and meta-analysis of the effect of donor demographics on post kidney transplant outcomes
}

\author{
Maria Irene Bellini ${ }^{1} @ \cdot$ Mikhail Nozdrin $^{2} \cdot$ Liset Pengel $^{3} \cdot$ Simon Knight $^{3} \cdot$ Vassilios Papalois $^{4}$
}

Received: 16 September 2021 / Accepted: 14 December 2021 / Published online: 24 January 2022

(c) The Author(s) 2022

\begin{abstract}
Background and Aims Living donor kidneys are considered the best quality organs. In the attempt to expand the donor pool, the donor's age, sex and body mass index (BMI) might be considered as potential determinants of the kidney transplant outcomes, and thus guide recipient selection. We aimed to investigate the effects of donor demographics on kidney function, graft and recipient survival, delayed graft function (DGF) and acute rejection (AR).

Methods Systematic review and meta-analysis. EMBASE, MEDLINE, Web of Science, BIOSIS, CABI, SciELO and Cochrane were searched using algorithms. NHBLI tools were used for risk of bias assessment. Mean difference (MD), standardized mean difference (SMD), and risk ratio (RR) were calculated in Revman 5.4

Results Altogether, 5129 studies were identified by the search algorithm; 47 studies met the inclusion criteria and were analyzed. No significant difference in recipient 1-year survival was found between recipients of donors aged $<50$ vs donors aged $>50$ ( $R R=0.6595 \%$ CI: $0.1-4.1)$, and recipients of donors aged $<60$ vs donors aged $>60$ ( $R R=0.8195 \%$ CI: $0.3-2.3)$. Graft survival was significantly higher in recipients of grafts from donors aged $<60$. Risk of AR (RR $=0.6295 \%$ CI: $0.5-0.8)$ and DGF (RR $=0.2895 \% \mathrm{CI}: 0.1-0.9)$ were significantly lower in recipients of grafts from donors aged $<60$. One-year serum creatinine was significantly lower in recipients from donors aged $<60$ years compared to donors aged $>60$ years $(\mathrm{MD}=0.3 \mathrm{mg} / \mathrm{dl}$ 95\% CI: 0.1-0.9), although there was high heterogeneity. Recipients of grafts from male donors had lower 1-year serum creatinine (MD $=0.12 \mathrm{mg} / \mathrm{dl}$ 95\% CI: 0.2-0.1) and higher eGFR compared to recipients of female donors $(\mathrm{p}<0.00001)$. Donor obesity increased the incidence of delayed graft function but not acute rejection $(\mathrm{RR}=0.6695 \% \mathrm{CI}$ : $0.32-1.34)$.

Conclusions Older donor age was associated with worse post-transplant outcomes and recipients of male donors had better 1-year eGFR. Donor obesity affects the incidence of delayed graft function, but not the incidence of acute rejection in recipients.
\end{abstract}

Maria Irene Bellini

m.irene.bellini@gmail.com

1 Department of Surgical Sciences, Sapienza University

of Rome, 00161 Rome, Italy

2 Imperial College School of Medicine, London SW7 2AZ, UK

3 Centre for Evidence in Transplantation, Nuffield Department of Surgical Sciences, University of Oxford, Oxford OX3 7HE, UK

4 Department of Surgery and Cancer, Imperial College, London SW7 2AZ, UK 


\section{Graphical Abstract}

HOW GOOD IS A LIVING DONOR? SYSTEMATIC REVIEW

AND META-ANALYSIS OF THE EFFECT OF DONOR

DEMOGR APHIICS ON POST KIDNEY TRANSPLANT

OUTCOMES
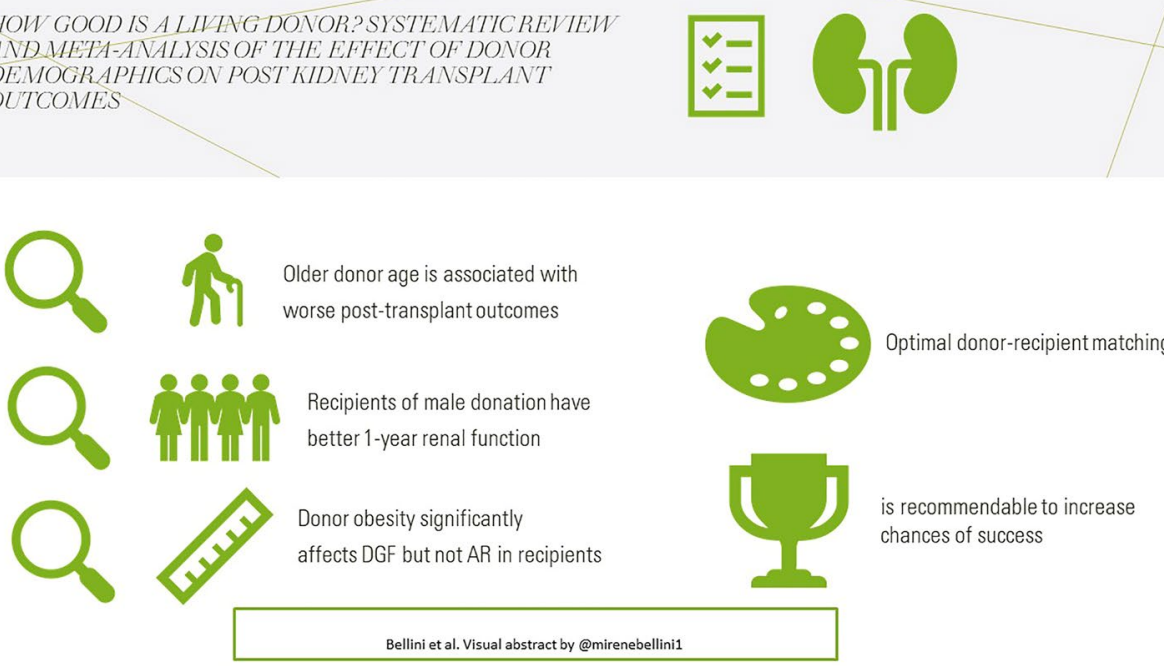

Keywords Living donation · Donor's demographics · Graft outcomes · Kidney transplantation

\section{Abbreviations}

AR Acute rejection

BMI Body mass index

DGF Delayed graft function

LD Living donor

LKD Living kidney donation

PNF Primary non function

\section{Introduction}

Long-lasting results after kidney transplantation are largely influenced by the quality of the organ received, with living kidney donation (LKD) offering the best transplant outcomes [1].

To manage the current organ donor shortage, the transplant community has progressively opened up to a broadening of the selection criteria for living donor candidates, in terms of donor age and body mass index (BMI), with no definitive cut-off being accepted [2].

In the case of deceased donation, strategies to improve outcomes consequent to the acceptance of extended criteria donors, namely a higher incidence of delayed graft function (DGF), [3] are currently under investigation, in consideration of the higher impact of an ischemic-reperfusion injury in these organs [4]. Yet, a comparable evaluation of extended criteria for living donors is missing, in particular with regard to the donor's demographic characteristics of sex, age and BMI.
It has been previously reported that a higher proportion of wife-to-husband donations and disproportionate femaleto-male donations among biological relatives and unrelated pairs, lead to gender inequality in kidney transplantation [5, 6]. The same inequity remains underrepresented in many clinical research studies, thus limiting the evidence based upon which to make recommendations to ensure the best outcomes.

With regard to BMI, controversy still exists, with some advocating bariatric surgery as a pre-donation procedure [7], and others excluding candidates who do not fit the center's criteria [8]. We previously investigated the effects of the recipients' demographic characteristics on outcomes of kidney grafts from living donors (LDs) [9]; the aim of the present study is to investigate the effects of LKD demographics on kidney graft function and survival.

\section{Methods}

The review was conducted and reported according to PRISMA guidelines [10], Fig. 1, and MOOSE criteria [11].

\section{Search strategy}

Literature searches were performed in Ovid (EMBASE, MEDLINE), Web of Science and Cochrane databases, using combinations of free text and keyword terms for living kidney donation and donor demographics of interest. Searches 


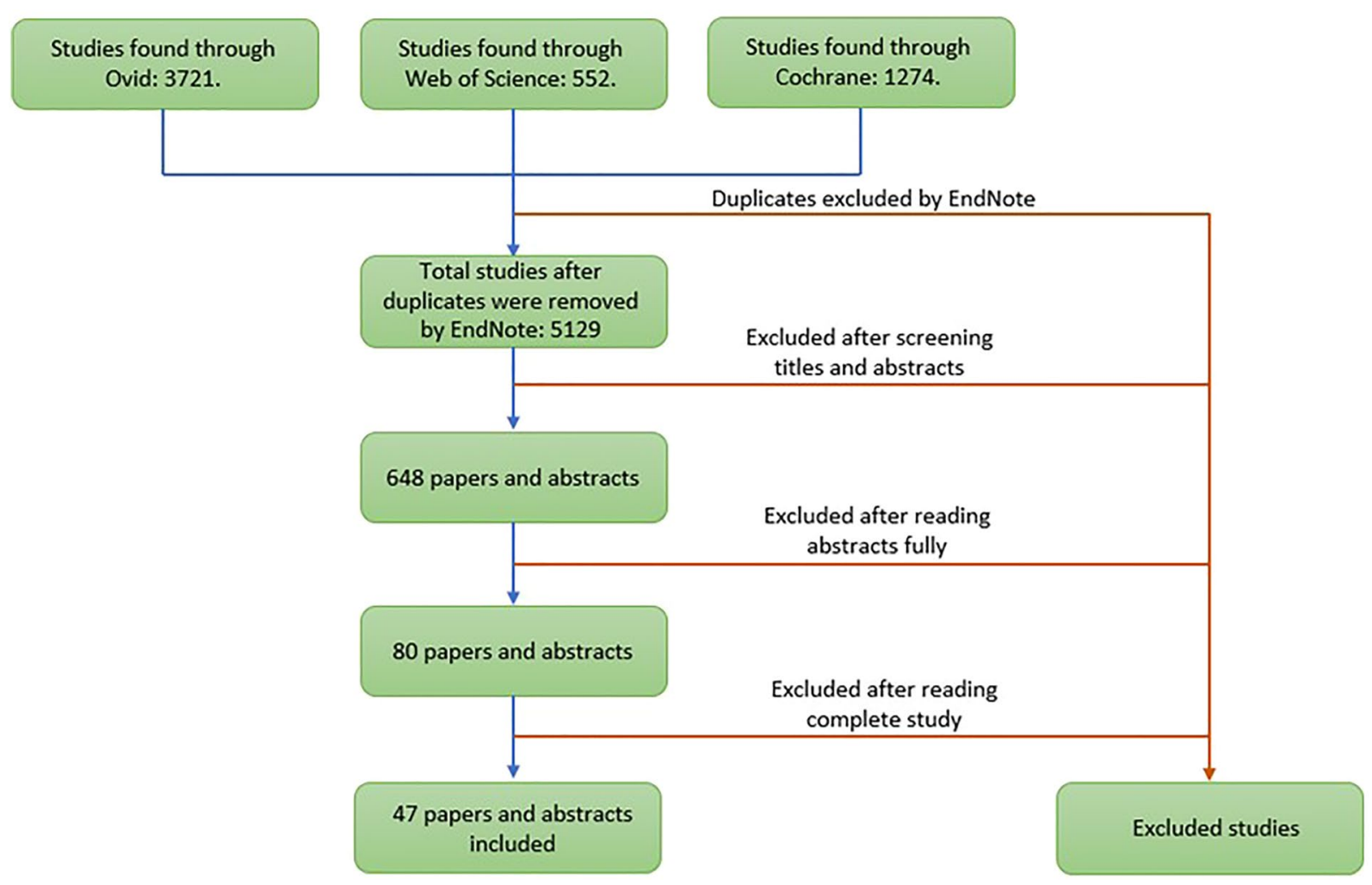

Fig. 1 PRISMA flowchart

were conducted on the 14/11/20 and are reported in Appendix 1 in ESM.

\section{Inclusion/exclusion criteria}

Any study relating living kidney donor demographics to recipient outcomes were eligible for inclusion, including full articles and meeting abstracts. Only studies in English were included for the analysis.

\section{Outcomes of interest}

The effect of donor demographics of age, sex, BMI, and genetic relationship to the recipient on patient survival and graft function evaluated using estimated glomerular filtration rate (eGFR) adjusted for body surface area and serum creatinine, proteinuria incidence, delayed graft function and acute rejection (AR) were investigated.

\section{Screening and data extraction}

Study identification and data extraction were performed in three stages: the first stage included downloading the studies identified by the search strategy from Cochrane, Ovid and Web of Science databases into EndNote reference management software. The reference management software was then used to remove duplicate studies. The second stage included two independent researchers (MIB and $\mathrm{MN}$ ) screening the titles and abstracts of long-listed studies. The researchers then each produced a list of studies they thought would be eligible for the review. The two lists were then compared to see whether one of the reviewers excluded a potentially viable study. A single short-list of studies selected for full text review was then produced. The third stage of data extraction included the researchers fully reading the short-listed studies and identifying the studies that met the inclusion criteria. Data extraction was performed by two independent reviewers (MIB and MN) and disagreements were solved by discussion or consulting a third reviewer. Data was extracted into a Microsoft Excel sheet.

\section{Risk of bias assessment}

Risk of bias assessment (Appendix 2 in ESM) was performed using the National Institute of Health National Heart, Lung and Blood Institute (NIH NHBLI) quality assessment tool [12]. Two independent reviewers, MIB and MN, judged the quality of the articles and compared their results. Risk of bias assessment was not carried out for congress abstracts included in the study (4 abstracts). 


\section{Meta-analysis}

All data analyses were performed in Revman 5.4.1 and IBM SPSS Statistics 26. Meta-analysis of mean difference was used for continuous data. Random effect models were used for all meta-analyses due to the heterogeneous and small study samples. Mean differences with a $95 \%$ confidence interval were calculated for the summary effect. The $\mathrm{Z}$ test was performed to calculate p-values. Where p-values were $<0.05$ and $95 \%$ CI did not include 0 , a statistically significant difference between the two groups was recorded. Forest plots were created in Revman 5.4.1.

When it was necessary to combine two reported subgroups into a single group for the meta-analysis (for example combining subgroups of donors aged 18-24 with donors aged $24-50$ into a single group to compare it against a group of donors over the age of 50), the formula for combining groups from the Cochrane handbook was used [13].

\section{Results}

\section{Effect of donor age}

Six studies reported the effect of donor age and recipient survival [14-19]; Grekas et al. [14], Johnson et al. [15] and Guo et al. [16] compared recipient survival from donors aged above/below 50 years (Fig. 2a).

One-year recipient survival from donors aged over/under 60 years was reported by Grekas et al. [14], Giessing et al. [17] and Beradinelli et al. [18] (Fig. 2b), with no significant difference $(p=0.32)$ being reported for the 3-year survival either (Fig. 2c).

\section{Effect of donor age on graft survival}

Six studies reported the effect of donor age and graft survival [14-16, 20-22], finding no significant difference in 1 -year graft survival between recipients of grafts from donors under/over 50 years of age (Fig. 2d).

Eleven studies compared 1-year graft survival between renal transplant recipients of donors aged under/over 60 years [17, 18, 20, 23-30], finding no significant difference (Fig. 2e).

Kumar et al. [20], De La Vega et al. [21], [21] and Jain et al. [31] compared the incidence of AR between recipients of a graft from donors younger than 50 years and donors older than 50 years. The analysis found no statistical difference between the two groups (Fig. 2f).

Four studies [17, 20, 25, 32] looked at AR incidence between graft recipients from $<60$ year-old or $>60$ year-old LDs. The analysis found that recipients of renal grafts from donors aged $<60$ have a $38 \%$ lower risk of developing acute rejection compared to recipients of renal grafts from donors aged $>60$ years $(\mathrm{p}=0.0004)$ (Fig. $2 \mathrm{~g})$.

Four studies [14, 20,31,33] reported 1-year post-transplantation eGFR in recipients of renal grafts from donors aged $<50$ and donors aged $>50$ years (Fig. $2 \mathrm{~h}$ ). Medium effect size (0.46 95\% CI: 0.24-0.67) was seen between the eGFR means of recipients of renal grafts from donors aged $<50$ and recipients of renal grafts from donors $>50$, and this finding was statistically significant $(\mathrm{p}<0.0001)$.

Three studies[14, 20, 34] compared 1-year post-transplantation eGFR in recipients of renal grafts from donors aged younger than 60 and older than 60 years. Large size effect (1.09 95\% CI: -0.4 to 2.59) was seen between eGFR means of recipients of renal grafts from donors aged $<60$ and recipients of renal grafts from donors aged $>60$, however this finding was not statistically significant $(\mathrm{p}=0.15)$ (Fig. 2i).

Four studies[15, 16, 20, 35] compared 1-year serum creatinine in recipients of renal grafts from donors aged $<50$ and donors aged $>50$ years, finding the former on average $0.14 \mathrm{mg} / \mathrm{dl}$ lower than that of recipients of donors aged $>50$ $(\mathrm{p}=0.003)$ (Fig. 21).

Three studies $[17,19,20]$ compared 1-year post-transplantation serum creatinine in recipients of renal grafts from donors aged $<60$ and donors aged $>60$ years: again the former was on average $0.24 \mathrm{mg} / \mathrm{dl}$ lower than that of recipients of donors aged $>60(\mathrm{p}=0.01)($ Fig. $2 \mathrm{~m})$.

In the two studies by De La Vega et al. [21] and Duchenne et al. [22], when comparing serum creatinine between recipients who received a renal graft from a donor aged $<50$ and recipients who received a renal graft from a donor aged $>50$, no significant difference was found $(p=0.25)$.

Three studies $[18,24,26]$ compared DGF incidence between recipients of grafts from donors aged $<60$ and donors aged $>60$. The analysis found recipients of grafts from donors aged $<60$ to be $72 \%$ less likely to develop DGF compared to recipients of grafts from donors aged $>60$ $(\mathrm{p}=0.03)$, (Fig. 2n). No significant difference was found between the incidence of primary non function between the recipients who received a graft from donors aged $>60$ or $<60(p=0.88)$ in the two studies $[18,27]$ reporting on this outcome from donors aged $<60$ and recipients of donors aged $>60$.

Table 1 summarizes the evidence of proteinuria in living donor grafts stratified according to age, with no significant difference among grafts from under/over 50 years as well as in the comparison under/over 60 years.

\section{Effect of donor sex on graft survival}

Two studies [36, 37] compared non-death censored graft survival between recipients of grafts from male and female donors. Only Jacobs et al. [36] found recipients of grafts from male donors to have a significantly higher rate of 

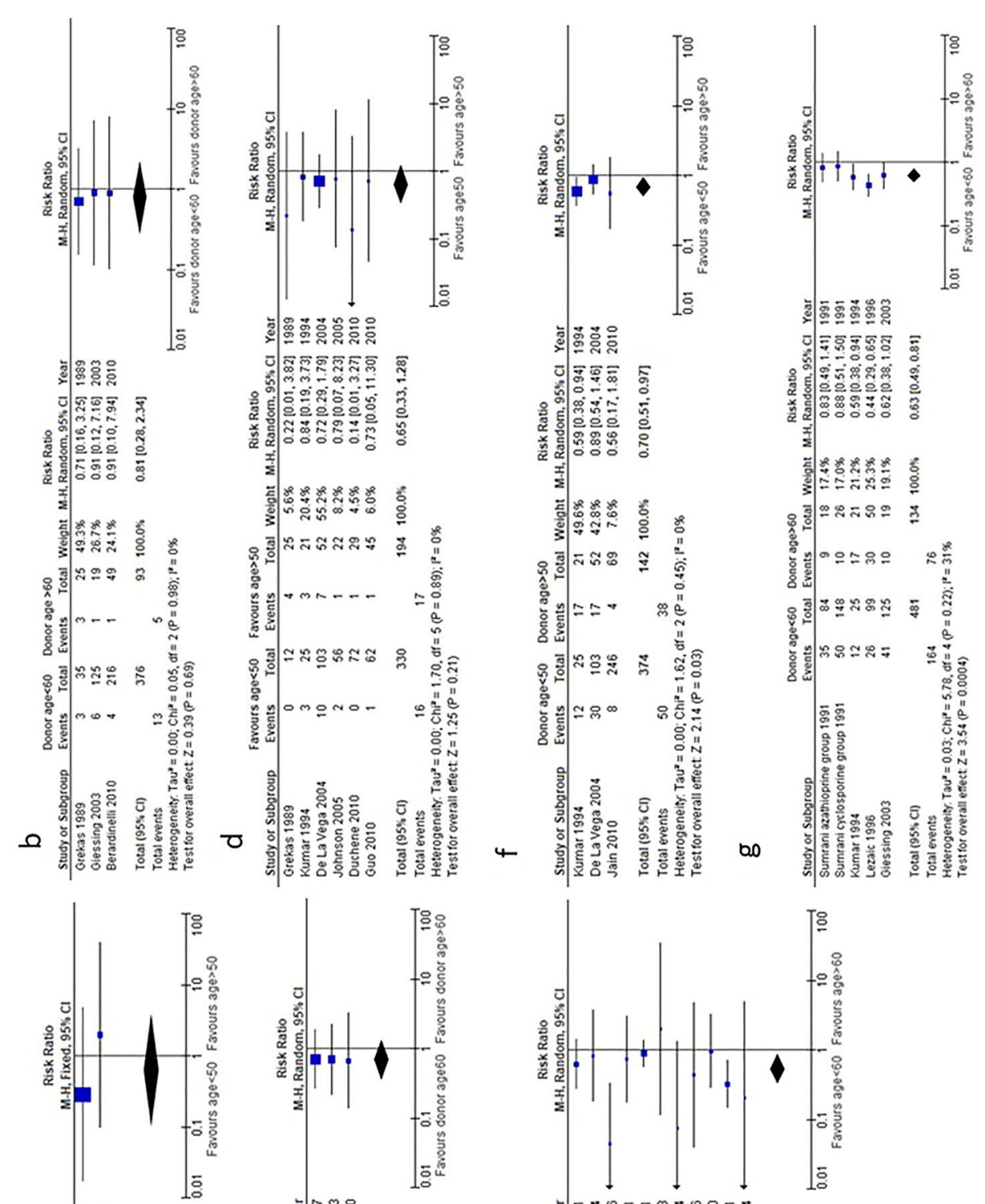

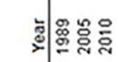

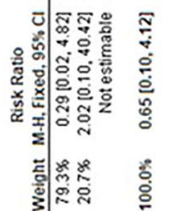

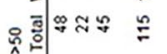

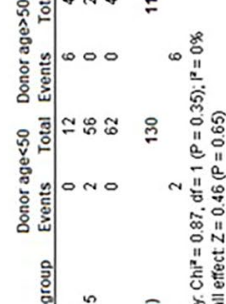

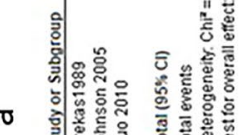

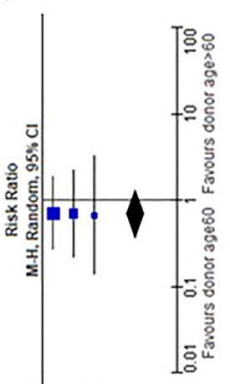

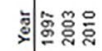

可忽河 票

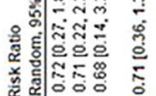

.

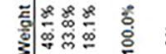

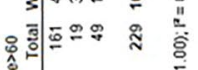

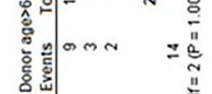

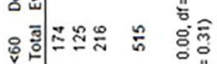

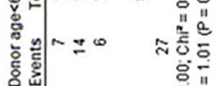

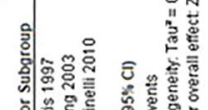

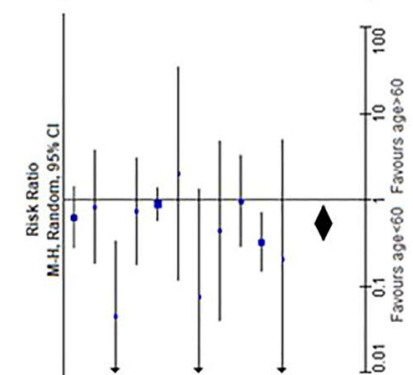

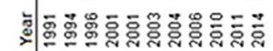

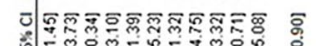

政

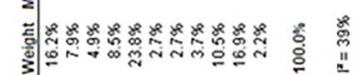

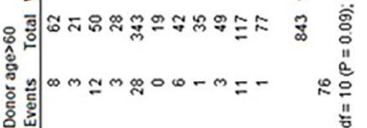

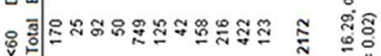

$\begin{array}{ccc} & 0 \\ & 0\end{array}$

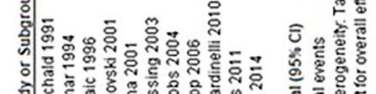

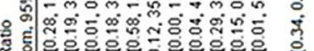

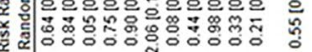

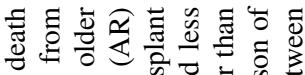

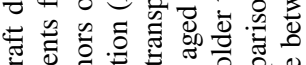

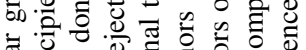

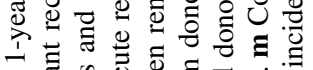

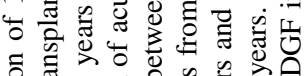

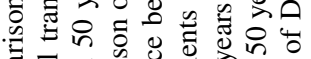

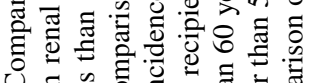

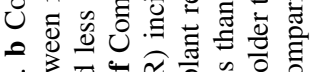

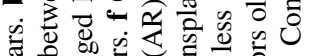

ऽ స

舟.

可

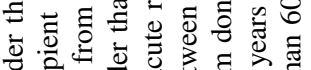

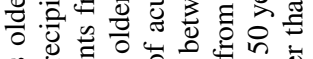

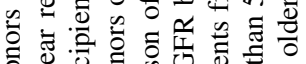

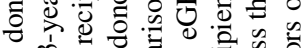

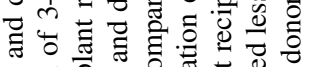

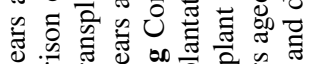

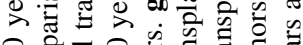

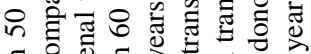

矛

U 屯

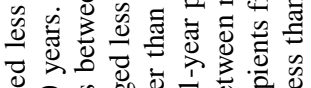

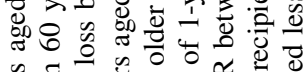

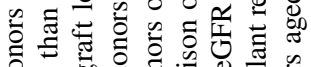

它战

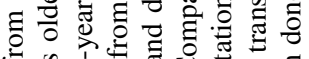

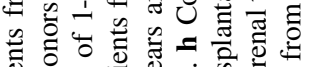

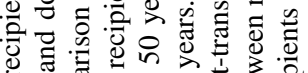

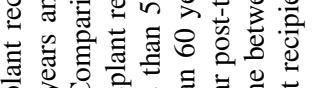

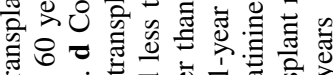

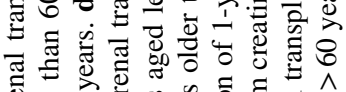

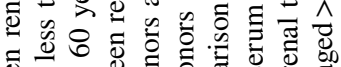

ఫ

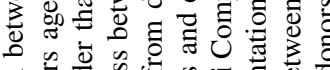

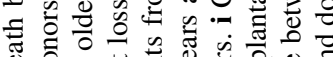

षㅎㅁ

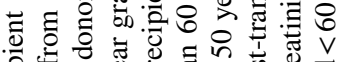

:

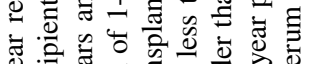

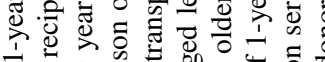

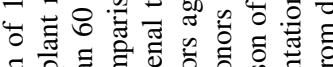

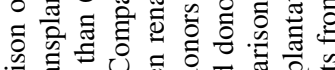

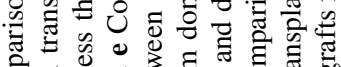

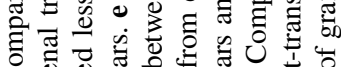

U

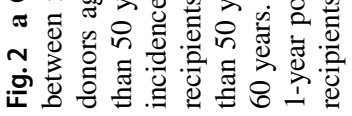



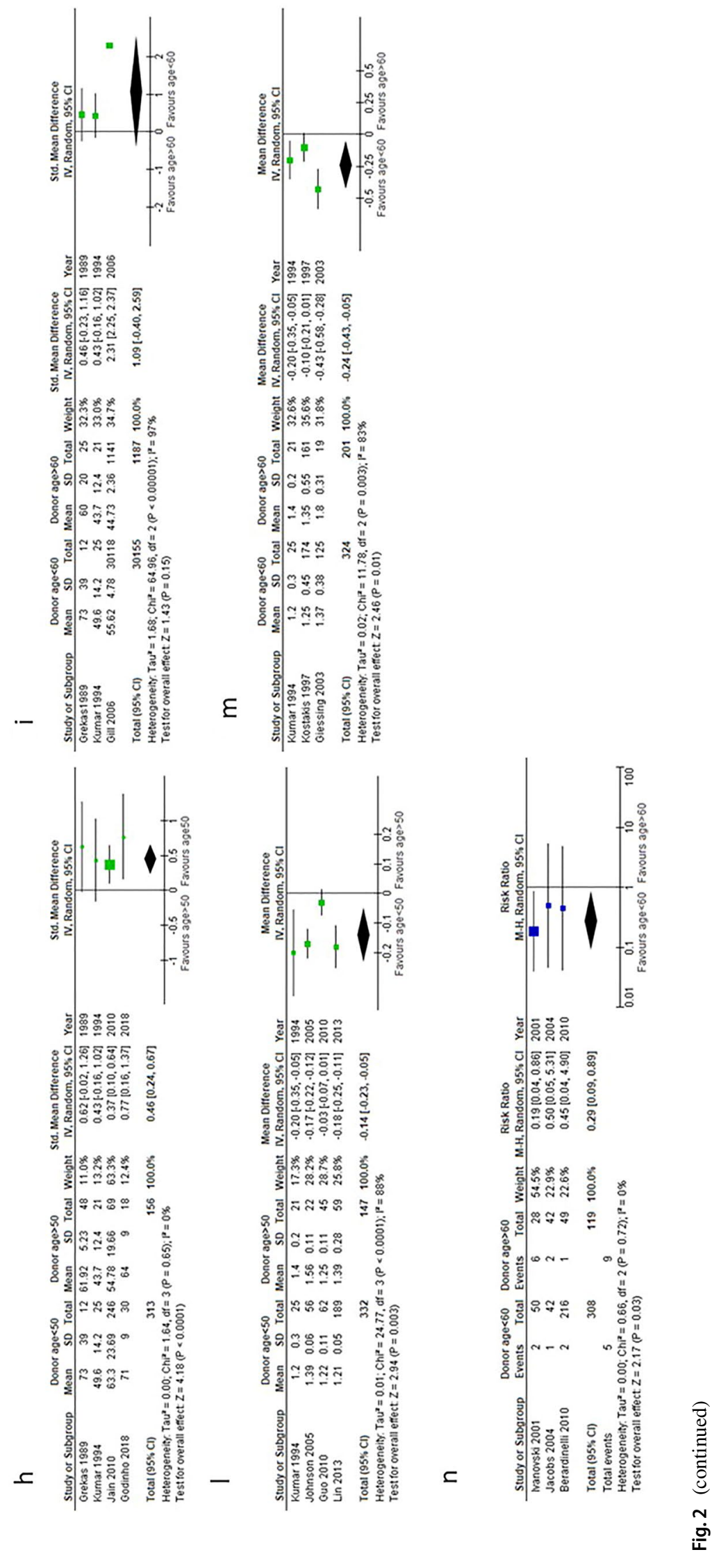
graft survival $(89.5 \%)$ compared to recipients of grafts from female donors $(83 \%)$ at 3 years post-transplantation $(\mathrm{p}=0.01)$, as shown in Table 2 . Neither study found any significant difference in recipient graft survival between recipients of grafts from donors of the same and opposite sex (Table 3).

Jacobs et al. [36] found no difference in 1-year graft survival in male recipients from male donors and female donors $(p=0.15)$. However, at 3-year follow-up, male recipients of grafts from male donors were found to have higher graft survival (93.2\%) compared to male recipients of grafts from female donors $(84.1 \%)(p=0.006)$. On the other hand, Wafa et al. [37] found no significant difference in male graft survival from male and female donors both at 5 -year $[p=0.97]$ and 10 -year $[p=0.31]$ post-renal transplantation (Table 4). Neither study found any significant difference in female recipient graft survival from male and female donors. This finding was seen in the studies at both shorter and longer periods after renal transplantation (Table 5).

\section{Effect of donor sex on renal function}

Five studies [35, 36, 38-40] investigating the effects of donor gender on recipient eGFR or serum creatinine met the inclusion criteria. Overall, recipients of grafts from male

Table 1 Effect of donor age on the development of proteinuria in renal transplant recipients

\begin{tabular}{|c|c|c|c|c|c|}
\hline \multirow[t]{2}{*}{ Proteinuria } & \multirow{2}{*}{$\begin{array}{l}\text { Proteinuria measure- } \\
\text { ment }\end{array}$} & \multicolumn{3}{|l|}{ Donor age } & \multirow{2}{*}{$\begin{array}{l}\text { Statistical sig- } \\
\text { nificance }\end{array}$} \\
\hline & & Age $<50$ & $55-60 \quad 60-65$ & Age $>70$ & \\
\hline \multirow[t]{2}{*}{$\begin{array}{l}\text { Johnson et al. } \\
\text { [15] }\end{array}$} & \multirow[b]{2}{*}{$\begin{array}{l}\text { Proteinuria was } \\
\text { measured on } \\
\text { postoperative day } \\
1,7,30,90,180,365 \\
\text { and } 730 . \text { Proteinu- } \\
\text { ria was defined as } \\
\text { significant if spot } \\
\text { analysis demon- } \\
\text { strated }>100 \text { mg of } \\
\text { protein in urine on } \\
\text { at least } 2 \text { occasions }\end{array}$} & $\begin{array}{l}\text { Proteinuria: } \\
21 / 56(37.5 \%)\end{array}$ & \multicolumn{2}{|l|}{ Proteinuria: 9/22 (40.1\%) } & $\begin{array}{l}\mathrm{P}=0.49(\mathrm{Chi} \\
\text { squared })\end{array}$ \\
\hline & & $\begin{array}{l}\text { Significant pro- } \\
\text { teinuria: } 10 / 56 \\
(17.9 \%)\end{array}$ & \multicolumn{2}{|l|}{ Significant proteinuria: 4/22(18.2\%) } & $\begin{array}{l}\mathrm{P}=0.6(\mathrm{Chi} \\
\text { squared })\end{array}$ \\
\hline \multirow[t]{2}{*}{ Grekas et al. [14] } & \multirow[t]{2}{*}{$\begin{array}{l}\text { Proteinuria was } \\
\text { measured } \mathrm{g} / 24 \mathrm{~h} \\
1 \text { year and } 2 \text { years } \\
\text { after transplantation }\end{array}$} & $\begin{array}{l}\text { 1-year post- } \\
\text { transplantation: } \\
(\mathrm{N}=12) ; \mathrm{A}: \\
0.5 \pm 0.3\end{array}$ & $\begin{array}{l}\text { 1-year post-transplantation: } \\
(\mathrm{N}=23): 0.3 \pm 0.1\end{array}$ & $\begin{array}{l}\text { 1-year post-transplantation: } \\
(\mathrm{n}=25) 0.3+-/ 0.1\end{array}$ & \multirow{2}{*}{$\begin{array}{l}\text { No statistical } \\
\text { difference was } \\
\text { found between } \\
\text { protein excre- } \\
\text { tion between } \\
\text { the } 3 \text { groups at } \\
1 \text { and } 2 \text { years }\end{array}$} \\
\hline & & $\begin{array}{l}\text { 2-year post- } \\
\text { transplantation: } \\
(\mathrm{N}=12) \\
0.3 \pm 0.2\end{array}$ & $\begin{array}{l}\text { 2-year post-transplantation: } \\
(\mathrm{N}=23): 0.3 \pm 0.2\end{array}$ & $\begin{array}{l}\text { 2-year post-transplantation: } \\
(\mathrm{n}=25) 0.3 \pm 0.1\end{array}$ & \\
\hline
\end{tabular}

Table 2 Effect of donor sex on non-death censored renal graft survival in recipient

Table 3 Effect of matching sex between donor and transplant recipient on non-death censored graft survival

\begin{tabular}{lllll}
\hline Study name & Recipient graft survival & \multicolumn{2}{l}{$\begin{array}{l}\text { Donor sex, recipient graft } \\
\text { survival }\end{array}$} & Chi squared test \\
\cline { 3 - 4 } & & Male & Female & \\
\hline Jacobs [30] & 1-year graft survival & $297 / 313$ & $391 / 417$ & $\mathrm{p}=0.52$ \\
& 3-year graft survival & $280 / 313$ & $346 / 417$ & $\mathrm{p}=0.01$ \\
Wafa [31] & 5-year graft survival & $154 / 180$ & $74 / 93$ & $\mathrm{p}=0.21$ \\
& 10-year graft survival & $103 / 180$ & $60 / 93$ & $\mathrm{p}=0.24$ \\
\hline
\end{tabular}

\begin{tabular}{lllll}
\hline Study name & Recipient graft survival & Same sex & Different sex & Chi squared test \\
\hline Jacobs[30] & 1-year graft survival & $323 / 339$ & $365 / 391$ & $\mathrm{P}=0.26$ \\
& 3-year graft survival & $295 / 339$ & $331 / 391$ & $\mathrm{P}=0.36$ \\
Wafa [31] & 5-year graft survival & $97 / 120$ & $131 / 153$ & $\mathrm{P}=0.28$ \\
& 10-year graft survival & $72 / 120$ & $91 / 153$ & $\mathrm{P}=0.93$ \\
\hline
\end{tabular}


Table 4 Non-death censored graft survival in male renal transplant recipients based on the gender of their donor

\begin{tabular}{lllll}
\hline Study name & Recipient graft survival & Male to male & Female to male & Chi squared test \\
\hline Jacobs [30] & 1-year graft survival & $157 / 162$ & $225 / 240$ & $\mathrm{P}=0.15$ \\
& 3-year graft survival & $151 / 162$ & $202 / 240$ & $\mathrm{P}=0.006$ \\
Wafa [31] & 5-year graft survival & $47 / 55$ & $24 / 28$ & $\mathrm{P}=0.97$ \\
& 10-year graft survival & $31 / 55$ & $19 / 28$ & $\mathrm{P}=0.31$ \\
\hline
\end{tabular}

\begin{tabular}{lllll}
\hline Study name & Recipient graft survival & Male to female & Female to female & Chi squared test \\
\hline Jacobs [30] & 1-year graft survival & $140 / 151$ & $166 / 177$ & $\mathrm{P}=0.7$ \\
& 3-year graft survival & $129 / 151$ & $144 / 177$ & $\mathrm{P}=0.32$ \\
Wafa [31] & 5-year graft survival & $107 / 125$ & $50 / 65$ & $\mathrm{P}=0.13$ \\
& 10-year graft survival & $72 / 125$ & $41 / 65$ & $\mathrm{P}=0.47$ \\
\hline
\end{tabular}

Table 5 Non-death censored graft survival in female renal transplant recipients based on the gender of their donor
With regard to the effect of sex matching between recipients of renal transplant from LDs on the development of proteinuria in recipients, results are summarized in Table 6; only Yanishi et al. [40] found proteinuria to be significantly lower in female recipients who had received a graft from a male donor compared to recipients who had received a transplant from a donor of the same gender and to male recipients who had received a renal graft from a female donor.

\section{Effect of donor BMI on recipient outcomes}

Three studies [41-43] compared DGF incidence in recipients of grafts from non-obese $(\mathrm{BMI}<30)$ and obese donors (BMI > 30). Recipients of grafts from non-obese donors had a $27 \%$ lower risk of developing DGF compared to recipients of grafts from obese donors $(\mathrm{p}=0.002)$, (Fig. 4a). Two studies [41, 44] compared the incidence of AR between recipients of renal grafts from donors with $\mathrm{BMI}<30$ and BMI $>30$, with no overall significant difference $(p=0.25)$.

\section{Effect of relationship between donor and recipient on outcomes in recipients}

Ten studies [17, 45-53] looked at the effect of the relationship between donor and recipient outcomes. In Figs. 4b, c, recipient survival at 1 -year and 10 years is favored by a biological relationship $(\mathrm{p}<0.0001)$.

The same beneficial effect of a genetic relationship between donor and recipient is noted on 1-year and 5-year graft survival (Figs. 4d, e).

In terms of graft function, with a mean follow-up of 45 months, Ahmad et al. [45] noted that eGFR was 59 \pm 29 in biologically related LDs versus $49 \pm 14 \mathrm{ml} / \mathrm{min} / 1.73 \mathrm{~m}^{2}$ in living unrelated donors (LURDs). Similar findings for serum creatinine were reported by Giessing et al. [17] and Brattstrom et al. [54] 


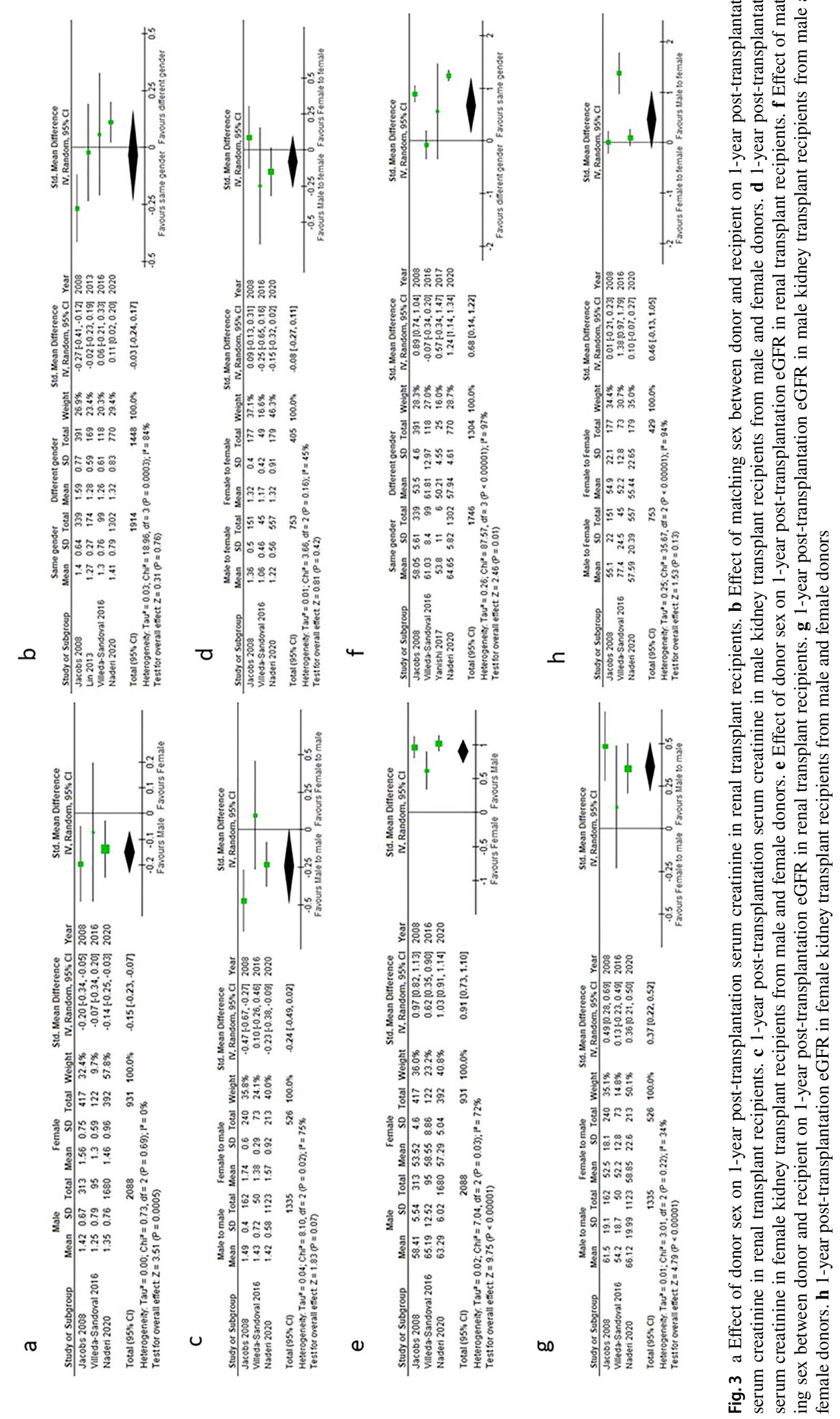


Table 6 Effect of matching recipient's sex with the sex of their donor on the post-transplantation proteinuria

\begin{tabular}{|c|c|c|c|c|c|c|}
\hline Study & $\begin{array}{l}\text { Proteinuria meas- } \\
\text { urement }\end{array}$ & Male to Male & Male to Female & Female to female & Female to male & $\begin{array}{l}\text { Outcomes reported } \\
\text { in the paper }\end{array}$ \\
\hline Oh et al. [35] & $\begin{array}{l}\text { Proteinuria } \\
\text { measured } 24 \mathrm{~h} \\
\text { post-surgery in } \\
\text { mg/day }\end{array}$ & $\begin{array}{l}\mathrm{MM}(\mathrm{n}=65) \\
23.4 \pm 61.6\end{array}$ & $\begin{array}{l}M F(n=34) \\
81.9 \pm 354.4\end{array}$ & $\begin{array}{l}\mathrm{FF}(=29): \\
9.7 \pm 51.6\end{array}$ & $\begin{array}{l}\mathrm{FM}(\mathrm{n}=67) \\
36.1 \pm 123.8\end{array}$ & $\begin{array}{l}\text { Independent sample } \\
\text { t-test: MM-FM } \\
(\mathrm{p}=0.461), \text { MF-FF } \\
(\mathrm{p}=0.282) ; \mathrm{MM}-\mathrm{MF} \\
(\mathrm{p}=0.198), \mathrm{FM}-\mathrm{FF}: \\
(\mathrm{p}=0.273)\end{array}$ \\
\hline Yanishi [34] & $\begin{array}{l}\text { Proteinuria } \\
\text { measured 1-year } \\
\text { post-surgery in } \\
\text { mg/day }\end{array}$ & $\begin{array}{l}\text { Group 1(same } \\
\text { gender) } \mathrm{n}=6: \\
135.2 \pm 98.1\end{array}$ & $\begin{array}{l}\text { group 2: (male donor } \\
\text { to female recipient) } \\
(\mathrm{n}=8) .63 .7 \pm 28.7\end{array}$ & $\begin{array}{l}\text { Group 1(same } \\
\text { gender) } \mathrm{n}=6 \text { : } \\
135.2 \pm 98.1\end{array}$ & $\begin{array}{l}\text { Group 3: female } \\
\text { donor to male } \\
\text { recipient }(n=17) \text { : } \\
205.5 \pm 35.2\end{array}$ & $\begin{array}{l}\text { ANOVA between the } \\
3 \text { groups found the } \\
\text { lowest proteinuria } \\
\text { to be in the Male } \\
\text { to Female group } \\
(\mathrm{p}<0.01)\end{array}$ \\
\hline
\end{tabular}

Along the same line, even DGF incidence favored genetically related LDs (Fig. 4f), although not significantly, while contrasting results are reported on the incidence of AR.

\section{Discussion}

Kidney transplant survival severely hinders the quality of the implanted graft, with living donation offering numerous advantages on recipient outcomes due to a better intrinsic quality of the implanted organ and the lower susceptibility to ischemic reperfusion injury [55]. In the present review, we looked at the evidence of how the demographic factors of age, sex, BMI and genetic relationship with the recipient influence post-transplant survival, graft function and acute rejection. These findings need consideration for guidance on donor-recipient matching, with particular regard to the implementation of sharing schemes, including poorly matched couples, thus providing new possibilities for prospective couples.

With regard to age, our analysis found that recipients of grafts from LDs aged $<60$ have a $38 \%$ lower risk of developing acute rejection compared to those aged $>60$ years. This result leads to the open debate on immunosuppression in the elderly, in whom, although physiological immunosenescence linked to biological aging is known, other potential contributors, such as the engraftment of older organs, is associated with higher rejection rates, and thus the need for tailored, age-adopted immunosuppression [56].

Additionally, this finding might also be the consequence of a more distant biological relationship in aged couples, where the donation is usually between spouses, as opposed to younger ones, where instead the donation happens more often between related subjects [25].

Furthermore, recipients of grafts from donors aged $<60$ are $72 \%$ less likely to develop DGF compared to recipients of grafts from donors aged $>60(p=0.03)$, in agreement with previous reports on the link between DGF and acute rejection [57]. An interesting finding is that proteinuria in recipients of LD grafts stratified according to age, shows no significant difference between older and younger donors, highlighting that the intrinsic quality, i.e. the podocyte barrier, is still high as LDs are healthy, screened individuals.

In the present meta-analysis, as in the case of standard donor criteria, we found superior one-year eGFR in recipients of grafts from donors younger than 50 years, compared to those older than 50 years; this effect was not confirmed when using 60 years as a cut-off, although in the latter case we noted a potentially large effect size (1.09 95\%CI: -0.4 to 2.59) and a smaller number of included studies (three versus four). A complete discussion of the effect size for each of the parameters considered is presented in Appendix 3 in ESM.

With regard to the effect of LD sex on eGFR post-transplantation, recipients of grafts from male donors were found to have a significantly higher eGFR compared to recipients of female donors $(\mathrm{p}<0.00001)$. This might be linked to a nephron mass effect [58], but it is controversial whether other possible factors could be concurring, considering the higher incidence of chronic kidney disease in women.

Looking at donor BMI, recipients of grafts from nonobese donors had a $27 \%$ lower risk of developing DGF compared to recipients of grafts from obese donors $(p=0.002)$, while regarding the incidence of acute rejection, no overall significant difference in acute rejection was observed.

Finally, concerning the genetic relationship with the recipient, graft function and survival were favored by the biological link between donor and recipient, possibly in relation of better histocompatibility [59], that also reduces the incidence of acute rejection, as previously discussed. Given that some transplant candidates may have multiple potential donors to choose from, a better understanding of the association between donor-recipient biological relationship 

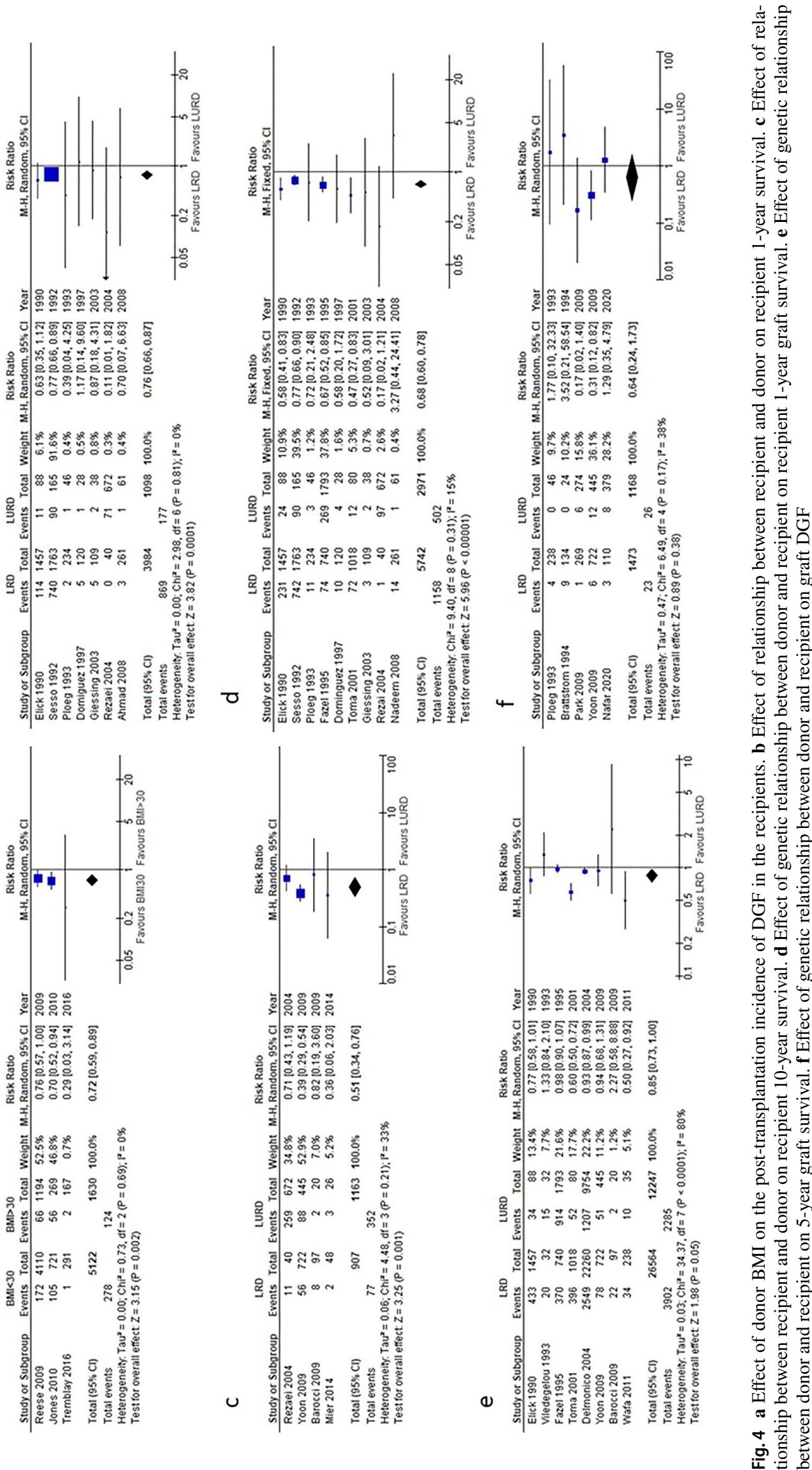

ㄴ.-유.

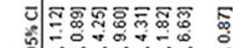

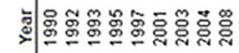

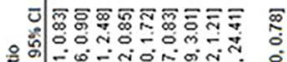

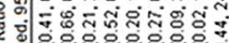

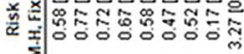

혼.

폴

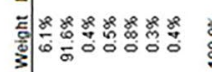

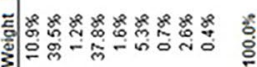

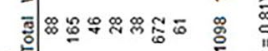

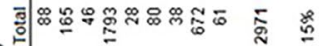

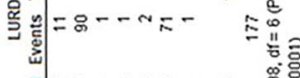

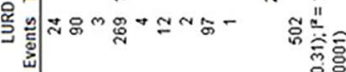

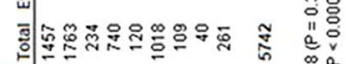

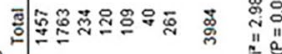

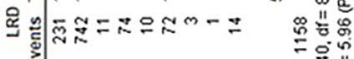

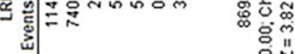

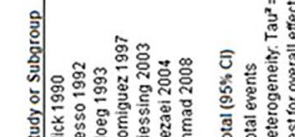

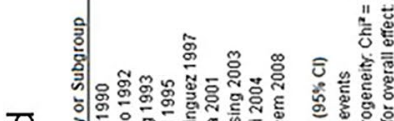

in

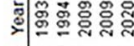

대을

을

줄

홀

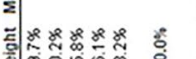

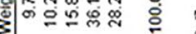

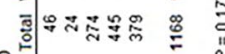

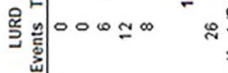

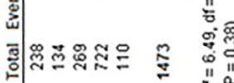

政券

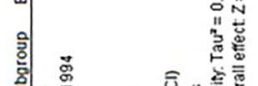

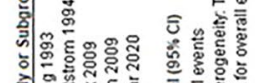

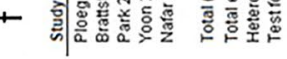

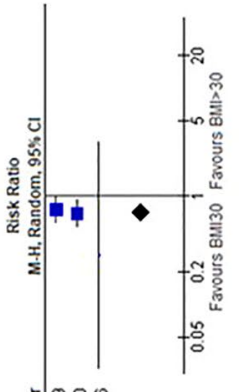

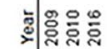

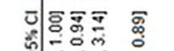

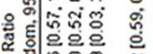

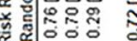

푤

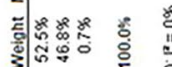

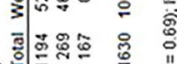

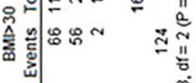

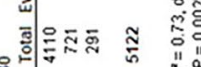

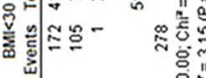

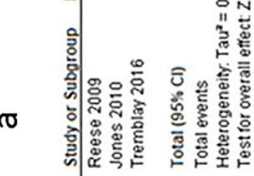

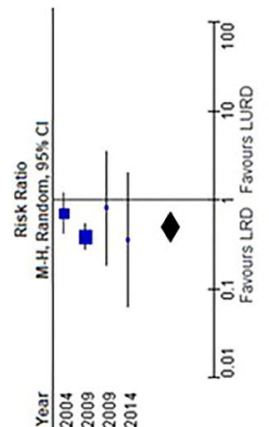

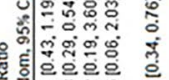

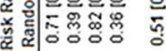

․․

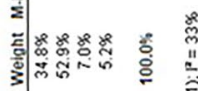

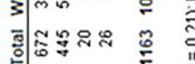

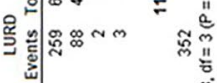

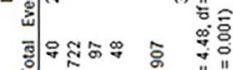

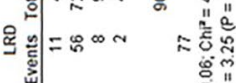

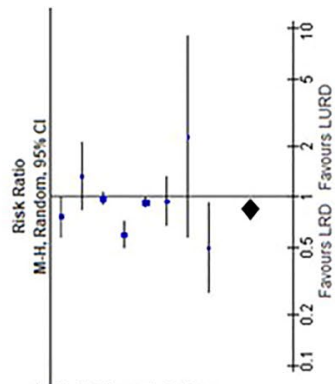

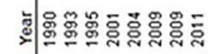

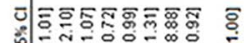

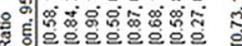

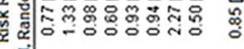

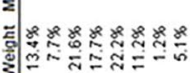

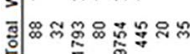

으

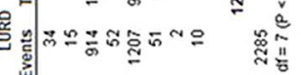

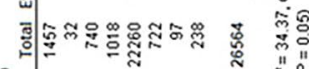

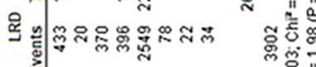

产

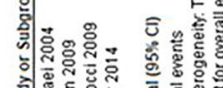

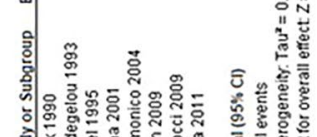

(1)

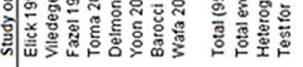

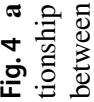


and post-transplant outcomes can improve donor selection. Notably, living donation among elderly subjects ( $>60$ years) almost always occurs between unrelated recipients and our data show that,therefore, also recipient factors, such as older age might influence graft survival.

\section{Limitations}

The retrospective nature of the analyzed studies limits the level of evidence we were able to achieve, based on observational registry data, a small number of studies and considerable heterogeneity.

\section{Conclusion}

In conclusion, the age of LDs is likely to impact on recipient outcomes. Donor BMI affects DGF incidence, and recipients of genetically related and male donors have better 1-year eGFR and graft survival. Future larger studies are warranted to identify the optimal donor-recipient matching and to guide towards establishing living donor exchange programs, even internationally, or involving compatible pairs, in order to generate more exchange opportunities and achieve better results.

Supplementary Information The online version contains supplementary material available at https://doi.org/10.1007/s40620-021-01231-7.

\section{Declarations}

Conflict of interest The authors declare no conflict of interest

Ethical approval The study, performed in accordance to the Declaration of Helsinki principles, is a retrospective analysis. The data used were anonymised; the study did not require patient or public involvement nor affected patient care. The study fell under the category of research through the use of anonymised data of existing databases which, based on the Health Research Authority criteria, does not require proportional or full ethics review and approval.

Open Access This article is licensed under a Creative Commons Attribution 4.0 International License, which permits use, sharing, adaptation, distribution and reproduction in any medium or format, as long as you give appropriate credit to the original author(s) and the source, provide a link to the Creative Commons licence, and indicate if changes were made. The images or other third party material in this article are included in the article's Creative Commons licence, unless indicated otherwise in a credit line to the material. If material is not included in the article's Creative Commons licence and your intended use is not permitted by statutory regulation or exceeds the permitted use, you will need to obtain permission directly from the copyright holder. To view a copy of this licence, visit http://creativecommons.org/licenses/by/4.0/.

\section{References}

1. Reese PP, Boudville N, Garg AX (2015) Living kidney donation: outcomes, ethics, and uncertainty. Lancet 385(9981):2003-2013

2. Bellini MI, Charalampidis S, Stratigos I, Dor F, Papalois V (2019) The effect of donors' demographic characteristics in renal function post-living kidney donation. Analysis of a UK Single Centre Cohort. J Clin Med 8:6

3. Ahmadi AR, Lafranca JA, Claessens LA, Imamdi RMS, IJzermans JNM, Betjes MG, Dor FJMF (2015) Shifting paradigms in eligibility criteria for live kidney donation: a systematic review. Kidney Int 87(1):31-45

4. Bellini MI, Yiu J, Nozdrin M, Papalois V (2019) The effect of preservation temperature on liver, kidney, and pancreas tissue ATP in animal and preclinical human models. J Clin Med 8:9

5. Kayler LK, Rasmussen CS, Dykstra DM, Ojo AO, Port FK, Wolfe RA, Merion RM (2003) Gender imbalance and outcomes in living donor renal transplantation in the United States. Am J Transpl 3(4):452-458

6. Piccoli GB, Alrukhaimi M, Liu ZH, Zakharova E, Levin A (2018) What we do and do not know about women and kidney diseases; questions unanswered and answers unquestioned: reflection on world kidney day and international women's day. Nephron 138(4):249-260

7. Nguyen MJP, Carpenter D, Tadros J, Mathur A, Sandoval PR, Woodle ES, Diwan T, Ratner LE (2019) Bariatric surgery prior to living donor nephrectomy: a solution to expand the living donor kidney pool—a retrospective study. Transpl Int 32(7):702-709

8. Oniscu GC, Abramowicz D, Bolignano D, Gandolfini I, Hellemans R, Maggiore U, Nistor I, O'Neill S, Sever MS, Koobasi M et al (2021) Management of obesity in kidney transplant candidates and recipients: a clinical practice guideline by the Descartes working group of ERA. Nephrol Dial Transplant 2021:5

9. Bellini MI, Nozdrin M, Pengel L, Knight S, Papalois V (2021) The impact of recipient demographics on outcomes from living donor kidneys: systematic review and meta-analysis. J Clin Med 10(23):5556

10. Page MJ, McKenzie JE, Bossuyt PM, Boutron I, Hoffmann TC, Mulrow CD, Shamseer L, Tetzlaff JM, Akl EA, Brennan SE et al (2021) The PRISMA 2020 statement: an updated guideline for reporting systematic reviews. BMJ 372:71

11. Stroup DF, Berlin JA, Morton SC, Olkin I, Williamson GD, Rennie D, Moher D, Becker BJ, Sipe TA, Thacker SB (2000) Meta-analysis of observational studies in epidemiology: a proposal for reporting. Meta-analysis Of Observational Studies in Epidemiology (MOOSE) group. JAMA 283(15):100

12. (2021) https://www.nhlbi.nih.gov/health-topics/study-qualityassessment-tools

13. (2021) https://training.cochrane.org/handbook/current

14. Grekas D, Alivanis P, Kalekou H, Spanos P, Tourkantonis A (1989) Kidney transplantation from living donors over 66 years of age. Transpl Proc 21(5):3851-3852

15. Johnson SR, Khwaja K, Pavlakis M, Monaco AP, Hanto DW (2005) Older living donors provide excellent quality kidneys: a single center experience (older living donors). Clin Transpl 19(5):600-606

16. Guo FF, Shao ZQ, Yang WY, Wang GJ, Tan SF, He XF, Wang JM, Liu HJ, Li Y, Sun FG et al (2010) Clinical analysis of living related renal transplantation with donors older than 50 years in China. Transpl Proc 42(7):2471-2476

17. Giessing M, Slowinski T, Deger S, Tuerk I, Schönberger S, Budde K, Loening SA (2003) 20-year experience with elderly donors in living renal transplantation. Transpl Proc 35(8):2855-2857 
18. Berardinelli L, Pozzoli E, Beretta C, Consonni D, Carini M, Rossini G, Scalamogna M (2010) Long-term Outcome of Living Donors Older Than 60 Years. Transpl Proc 42(4):1111-1113

19. Kostakis A, Bokos J, Stamatiades D, Zavos G, Boletis J, Papadogianakis J, Stathakis C, Skalkeas G (1997) The 10 years single center experience of using elderly donors for living related kidney transplantation. Geriatr Nephrol Urol 7(3):127-130

20. Kumar A, Kumar RV, Srinadh ES, Bhandari M, Sharma RK, Gupta A, Kher V (1994) Should elderly donors be accepted in a live related renal transplant program? Clin Transpl 8(6):523-526

21. De La Vega LSP, Torres A, Bohorquez HE, Heimbach JK, Gloor JM, Schwab TR, Taler SJ, Nyberg SL, Ishitani MB, Prieto M et al (2004) Patient and graft outcomes from older living kidney donors are similar to those from younger donors despite lower GFR. Kidney Int 66(4):1654-1661

22. Duchene DA, Woodruff DY, Gallagher BL, Aubert HA, Katz D, Dunn TB, Winfield HN (2010) Successful outcomes of older donors in laparoscopic donor nephrectomy. J Endourol 24(10):1593-1596

23. Lee S, Kim J, Choi S, Yoon K, Yun N, Oh C, Shin G, Kim H, Kim S (2014) Age-matching improves graft survival after living donor kidney transplantation: abstract\# C1903. Transplantation 2014:98

24. Jacobs SC, Ramey JR, Sklar GN, Bartlett ST (2004) Laparoscopic kidney donation from patients older than 60 years 11 No competing interests declared. J Am Coll Surg 198(6):892-897

25. Lezaić V, Djukanović L, Blagojević-Lazić R, Radivojević D, Marković V, Petronić V, Borić Z, Marinković J (1996) Living related kidney donors over 60 years old. Transpl Int 9(2):109-114

26. Ivanovski N, Popov Z, Kolevski P, Cakalaroski K, Stojkovski L, Spasovski G, Paneva-Masin J (2001) Use of advanced age donors in living renal transplantation-is it justified? Transpl Proc 33(1): 1227-1228

27. Neipp M, Jackobs S, Jaeger M, Schwarz A, Lueck R, Gwinner W, Becker T, Klempnauer J (2006) Living kidney donors $>60$ years of age: is it acceptable for the donor and the recipient? Transpl Int 19(3):213-217

28. Fauchald P, Sødal G, Albrechtsen D, Leivestad T, Berg KJ, Flatmark A (1991) The use of elderly living donors in renal transplantation. Transpl Int 4(1):51-53

29. Dols LF, Kok NF, Roodnat JI, Tran TC, Terkivatan T, Zuidema WC, Weimar W, Ijzermans JN (2011) Living kidney donors: impact of age on long-term safety. Am J Transpl 11(4):737-742

30. Toma H, Tanabe K, Tokumoto T, Shimizu T, Shimmura H (2001) Time-dependent risk factors influencing the long-term outcome in living renal allografts: donor age is a crucial risk factor for long-term graft survival more than 5 years after transplantation. Transplantation 72:5

31. Jain N, Airy M, Kumari P, Hull D, Ranga KV (2010) Significant decrease in glomerular filtration rate at 5 years posttransplantation in the recipients of live donor kidneys 50 years of age or older. Transpl Proc 42(5):1648-1653

32. Sumrani N, Delaney V, Ding ZK, Davis R, Daskalakis P, Tejani A, Butt K, Hong J (1991) Renal transplantation from elderly living donors. Transplantation 51(2):305-309

33. Godinho I, Guerra J, Melo MJ, Neves M, Gonçalves J, Santana MA, Gomes da Costa A (2018) Living-donor kidney transplantation: donor-recipient function correlation. Transpl Proc 50(3):719-722

34. Gill JS, Gill J, Rose C, Zalunardo N, Landsberg D (2006) The older living kidney donor: part of the solution to the organ shortage. Transplantation 82:12
35. Lin J, Zheng X, Xie Z-1, Sun W, Zhang L, Tian Y, Guo Y-w (2013) Factors potentially affecting the function of kidney grafts. Chin Med J 126:9

36. Jacobs SC, Nogueira JM, Phelan MW, Bartlett ST, Cooper M (2008) Transplant recipient renal function is donor renal massand recipient gender-dependent. Transpl Int 21(4):340-345

37. Wafa EW, Shokeir AA, Akl A, Hassan N, Fouda MA, El Dahshan K, Ghoneim MA (2011) Effect of donor and recipient variables on the long-term live-donor renal allograft survival in children. Arab J Urol 9(2):85-91

38. Naderi G, Azadfar A, Yahyazadeh SR, Khatami F, Aghamir SMK (2020) Impact of the donor-recipient gender matching on the graft survival from live donors. BMC Nephrol 21(1):5

39. Villeda-Sandoval CI, Rodríguez-Covarrubias F, Gomez-Conzatti YMA, Lara-Nuñez D, Guinto-Nishimura GY, González-Sánchez B, Magaña-Rodríguez JD, Alberú-Gómez J, Vilatobá-Chapa M, Gabilondo-Pliego B (2016) The impact of donor-to-recipient gender match and mismatch on the renal function of living donor renal graft recipients. Gac Med Mex 152(5):645-650

40. Yanishi M, Tsukaguchi H, Huan NT, Koito Y, Taniguchi H, Yoshida K, Mishima T, Sugi M, Kinoshita H, Matsuda T (2017) Correlation of whole kidney hypertrophy with glomerular overfiltration in live, gender-mismatched renal transplant allografts. Nephrol (Carlton) 22(12):1002-1007

41. Reese PP, Feldman HI, Asch DA, Thomasson A, Shults J, Bloom RD (2009) Short-term outcomes for obese live kidney donors and their recipients. Transplantation 88(5):662-671

42. Jones H, Nogueira J, Haririan A, Jacobs S, Weir MR, Cooper M (2010) The effect of living kidney donor obesity on recipient renal outcomes. Am J Transpl 10(SUPPL. 4):536. https://doi.org/10. 1111/j.1600-6143.2010.03108.x

43. Tremblay S, Kaiser TE, Alloway RR, Woodle ES, Diwan TS (2016) Absence of the effect of pretransplant body mass index on post kidney transplant outcomes. Prog Transpl 26(2):183-190

44. Espinoza R, Gracida C, Cancino J, Ibarra A (2006) Effect of obese living donors on the outcome and metabolic features in recipients of kidney transplantation. Transpl Proc 38(3):888-889

45. Ahmad N, Ahmed K, Khan MS, Calder F, Mamode N, Taylor J, Koffman G (2008) Living-unrelated donor renal transplantation: an alternative to living-related donor transplantation? Ann R Coll Surg Engl 90(3):247-250

46. Rezaei M, Kazemnejad A, Bardideh A, Mahmoudi M (2004) Factors affecting survival in kidney recipients at kermanshah. Urol J 1(3):180-187

47. Sesso R, Klag MJ, Ancao MS, Whelton PK, Seidler A, Sigulem D, Ramos OL (1992) Kidney transplantation from living unrelated donors. Ann Intern Med 117(12):983-989

48. Domíguez J, Zayas E, Malavé M, González Z, Morales LA, Rive Mora E, Santiago Delpín EA (1997) Living emotionally related donor transplantation as an approach to donor shortage in Puerto Rico. Transpl Proc 29(1):187-189

49. Elick BA, Sutherland DE, Gillingham K, Najarian JS (1990) Use of distant relatives and living unrelated donors: a strategy to increase the application of kidney transplantation to treat chronic renal failure. Transpl Proc 22(2):343-344

50. Ploeg RJ, Pirsch JD, Stegall MD, Armbrust MJ, Lorentzen DF, D'Alessandro AM, Knechtle SJ, Sollinger HW, Kalayoglu M, Belzer FO (1993) Living unrelated kidney donation: an underutilized resource? Transpl Proc 25(1 Pt 2):1532-1534

51. Mier MG, Lara-Gutierrez J, Garcia-Esquina J, Alvarado-Arenas R, Lopez MM, Budar-Fernandez L, Soto-Miranda E, HernandezMaldonado E, Gonzalez-Velazquez F (2014) Kidney transplantation from spousal donors have excellent patient/graft outcomes similar to living related kidney transplantation: 10-year single mexican center experience: abstract\# C1632. Transplantation 98:257 
52. Yoon HE, Song JC, Hyoung BJ, Hwang HS, Lee SY, Jeon YJ, Park SC, Choi BS, Kim YS, Moon IS et al (2009) Comparison of long-term outcomes between spousal transplants and other living unrelated donor transplants: single-center experience. Nephron Clin Pract 113(4):c241-c249

53. Barocci S, Fontana I, Santori G, Nocera A, Valente U (2009) Living-related and unrelated donors in kidney transplantation: a single center experience. Riv Ital Med Labor 5(1):50-54. http:// ovidsp.ovid.com/ovidweb.cgi? $\mathrm{T}=\mathrm{JS} \& \mathrm{PAGE}=$ reference $\& \mathrm{D}=$ emed11\&NEWS $=$ N\&AN=354724578. Accessed 5 Sep 2021

54. Brattström C, Wilczek H, Frödin L, Claesson K, Pettersson E, Backman U, Lindholm A, Groth CG (1994) Experience with genetically unrelated living donors in kidney transplantation: an important but not sufficiently utilized organ resource. Transpl Proc 26(3):1746-1747

55. Bellini MI, Courtney AE, McCaughan JA (2020) Living donor kidney transplantation improves graft and recipient survival in patients with multiple kidney transplants. J Clin Med 9:7

56. Krenzien F, ElKhal A, Quante M, Rodriguez Cetina Biefer H, Hirofumi U, Gabardi S, Tullius SG (2015) A rationale for age-adapted immunosuppression in organ transplantation. Transplantation 99(11):2258-2268

57. Weber S, Dienemann T, Jacobi J, Eckardt K-U, Weidemann A (2018) Delayed graft function is associated with an increased rate of renal allograft rejection: a retrospective single center analysis. PLoS ONE 13(6):e0199445-e0199445

58. Luyckx VA, Brenner BM (2010) The clinical importance of nephron mass. J Am Soc Nephrol 21(6):898

59. Husain SA, King KL, Sanichar N, Crew RJ, Schold JD, Mohan S (2021) Association between donor-recipient biological relationship and allograft outcomes after living donor kidney transplant. JAMA Netw Open 4(4):e215718-e215718

Publisher's Note Springer Nature remains neutral with regard to jurisdictional claims in published maps and institutional affiliations. 